\title{
The Silk Road Journey in the Marketplace as the Modern Time Pilgrimage
}

\section{Dhruba Karki}

\section{https://doi.org/10.3126/litstud v29i01.39596}

\begin{abstract}
The Silk Road journey embodies an individual's revelation, a universal process of transformation of consciousness. At times, people set for pilgrimages to holy sites; other times, they go on trekking through hills and mountains. Pilgrimages to sacred sites have been replaced by people's journey to discotheques, fashion centers and shopping malls in the marketplace in today's corporate world. What binds them together is the transformation of consciousness along the journey from the terrestrial to the celestial sphere. Specific human, including pilgrimage and business trip become popular when people, ranging from children to adult across cultures make them significant parts of their lives. Sound and images of disco, jazz, hip-hop, and pop-rock have entered the streets and hotels in cities, from Lhasa to London, Shanghai to San Francisco, Karachi to Kathmandu, and Tokyo to New York. In today's world of saturated media presence, images and icons of heroes and legends, motivated by commercial and popular appeal, are circulated with a greater speed, becoming simultaneously a shared mythic currency and continuity, the modern world embodiment of silk road business, and thus, crossing the East-West divide.
\end{abstract}

\section{Introduction}

The journey, with its shared underlying universal patterns of men's beliefs in transformation of consciousness through trials, embodies man's incessant pursuit of revelation. The journey refers to an act of travelling from one place to another for specific purposes, such as in pursuit of knowledge, in search of someone, and in quest of something. In the past, people used to go on pilgrimages to holy sites; in today's media saturated business world, individuals visit concerts, fashion centers, shopping malls and beauty pageants in the marketplace as a part of their pilgrimage to the holy site. The journey becomes central to lives of people, ranging from those primitive nomads to the modern time travellers. Initially the nomads along with their cattle, including goats, horses, cows and buffalos moved westward in Western Asia and Eastern Europe in search of food for themselves and pastures for their livestock. An inherent human impulse to move prompts a journey, a universal archetypal motif leading transformation of consciousness. People not only make arrangements of food and shelter in particular locations but also engage themselves in some recreational activities, momentary breaks from routine works. Moreover, their leisure time activities along with their everyday works become significant part of lives. Indigenous ethnic people's spare time entertaining events in specific locations form folklores, and these people's indigenous activities travel from the village to the city reaching a large audience diverse ranges. With a fast changing pace of life, people's pilgrimage to the holy site has now been replaced by their trips to 
the marketplace, an embodiment of the Silk Road journey. The following section delineates the concept of representation in cultural studies before examining the motif of journey.

\section{Representation and the journey}

Representation refers to producing and circulating meanings in a communication circuit. We construct meanings of cultural objects, such as food we eat, dress we were, and movie we watch. Meanings are produced and exchanged among people living in specific cultural space. Products we consume not only have material utilities but also cultural significance, and they represent ideas and values we attribute to our everyday performances. Performances are representations and individuals in a social circle produce and consume them for their class consciousness. For an example, when some friends visit The Himalayan Java for coffee in Thamel, they look around for their class consciousness expecting someone of the class in order to live with shared values of their social status and personal standard.

Representation means portraying of ideas through some cultural objects and characters, replicating relationships between those signs and ideas they embody. This paper underscores an intersection between a cultural object and the society producing that phenomenon in a circuit of communication from perspectives of cultural studies. In British anthropologist Stuart Hall's conception, culture is about shared values transmitted by the medium of language, visual or non-visual, through which individuals make sense of objects and experiences, and meanings produced and exchanged. Central to meaning and culture, language is a key repository of cultural values and meanings (1). Like Hall's assertion in Representation: Cultural Representations and Signifying Practices, Paul Du Gay, in Doing Cultural Studies: the Story of the Sony Walkman, claims that "culture describes the way of life of particular groups, peoples, nations or periods" (11). In Keywords, Raymond Williams, using metaphors of "tending" and "cultivating" crops and animals like in agriculture, emphasizes the process of human development as a cultural embodiment (11). In The Idea of Culture, Terry Eagleton's consideration of culture, not only as what we live by but also what we live for, infers to affection, intimacy, kinship, emotional fulfillment and intellectual enjoyment (131). By cultural representation, people understand signifying practices through which individuals communicate no matter which part of the world they reside in. This paper examines a media representation of a culturally other character as the corporate world's treatment of the non-white athlete.

Whereas Hall treats signs, including linguistic and non-verbal within systems of representation in line with production and consumption of meanings, Roland Barthes considers those artworks myths in communication processes. Eagleton's postulation of representation of social consciousness through characters aligns with José Ortega Gasset's treatment of changing paradigm in narrative, a paradigm shift from adventure tales to interesting characters. People reveal their cultural values and collective consciousness through various activities they engage in, including dresses they wear, foods they eat, rituals they perform, social circles they build, or places they visit. For an example, people visit Himalayan Java in Kathmandu for their middle class consciousness. They pay almost $\$ 2.50$ for a cup of coffee which they could buy for $\$ 00.25$ in 
ordinary restaurants in the city. Such a class consciousness can be reflected differently in eating habits of Americans and Nepalis. Similarly, eating products of McDonald's or KFC represents lower class consciousness in the United States, whereas it embodies a middle class consciousness in Nepal. In that sense, meanings are produced and exchanged in intersections of the material world and the conceptual sphere.

Hall examines the system of representation of verbal signs and visual images with meaningful references to certain ideas of those cultural objects represented (5). People's dresses and foods, among other objects, represent their belonging to certain cultural groups, members of the same communities, who live together with shared values and collective consciousness. Hall further illustrates representation as a link between the material world of things, events, and experiences with the conceptual world of meanings and signifying practices. Representations of cultural objects are subject to changing historical contexts and organized social systems (28). Considering representation as a process of constructing meanings through cultural objects, Hall underscores the dynamics of meanings in signifying practices (62). Meanings of certain verbal signs or visual images vary from culture to culture; representations change in a linear progression of space-time continuum. In the western context, a young gentleman in suit and tie attends a business meeting, so the dress code stands for formality, uniformity and discipline. The same person at sports club appears in hat, sports shoes and track-suits. You may again see him in casual attire in dance bars in downtown at night. Moreover, people wear suit and tie while participating in a funeral procession in American society, but it looks inappropriate in Nepalese society.

Within a purview of Hall's cultural representations as interactive processes of human activities, John Storey, in Cultural Studies and the Study of Popular Culture, examines culture as more an everyday practice than an aesthetic manifestation:

Culture in cultural studies is defined politically rather than aesthetically. The object of study in cultural studies is not culture defined in the narrow sense, as the objects of aesthetic excellence ('high art'); nor culture defined in an equally narrow sense, as a process of aesthetic, intellectual and spiritual development; but culture understood as the texts and practices of everyday life. (2)

Culture shared in a given community operates as the textual site in new areas of the humanities of which popular culture is a significant branch. Human actions and behaviors are considered their identity markers. Film, video and television mediate people's actions and materials they use, and thus, making them popular across the world.

The Silk Road journey of the Chinese merchant gives meaningful representations. One the one hand, the rising supremacy of China, in efforts to strengthen its command in a global stage on multiple fronts, ranging from military to economy, has rigorously been working to revive the Silk Road link. On the other hand, the world community could be benefitted from this ancient Chinese business plan since it has offered the world citizens manufacturing products for their daily purposes as well as construction materials for building infrastructures. In that way, China seems to conserve its rich cultural 
heritage while accelerating its economic progress at an unprecedented rate. Precisely, the Chinese merchant's circular journey in the Silk Road embodies mythic archetypal structures of the hero's journey.

\section{The motif of journey}

The physical journey from one place to another leads to a transformation of consciousness in a process of psychological journey. It is a journey from the unconscious to conscious, inner to the outer, and the unknown to known. In myth, the hero's journey to the uncharted territory represents an individual's exploration to the vastness of universe in pursuit of revelation. In the past, an individual's pilgrimage to the holy site was meant for the making of the body sacred while refining the soul. It was a physical journey meant for spiritual transformation. In today's media world, people would rather stay home viewing film and watching television. If they like to move, they would rather go to concerts, fashion centers, and shopping malls. So the pilgrimage has now been replaced by travel, expedition, or excursion.

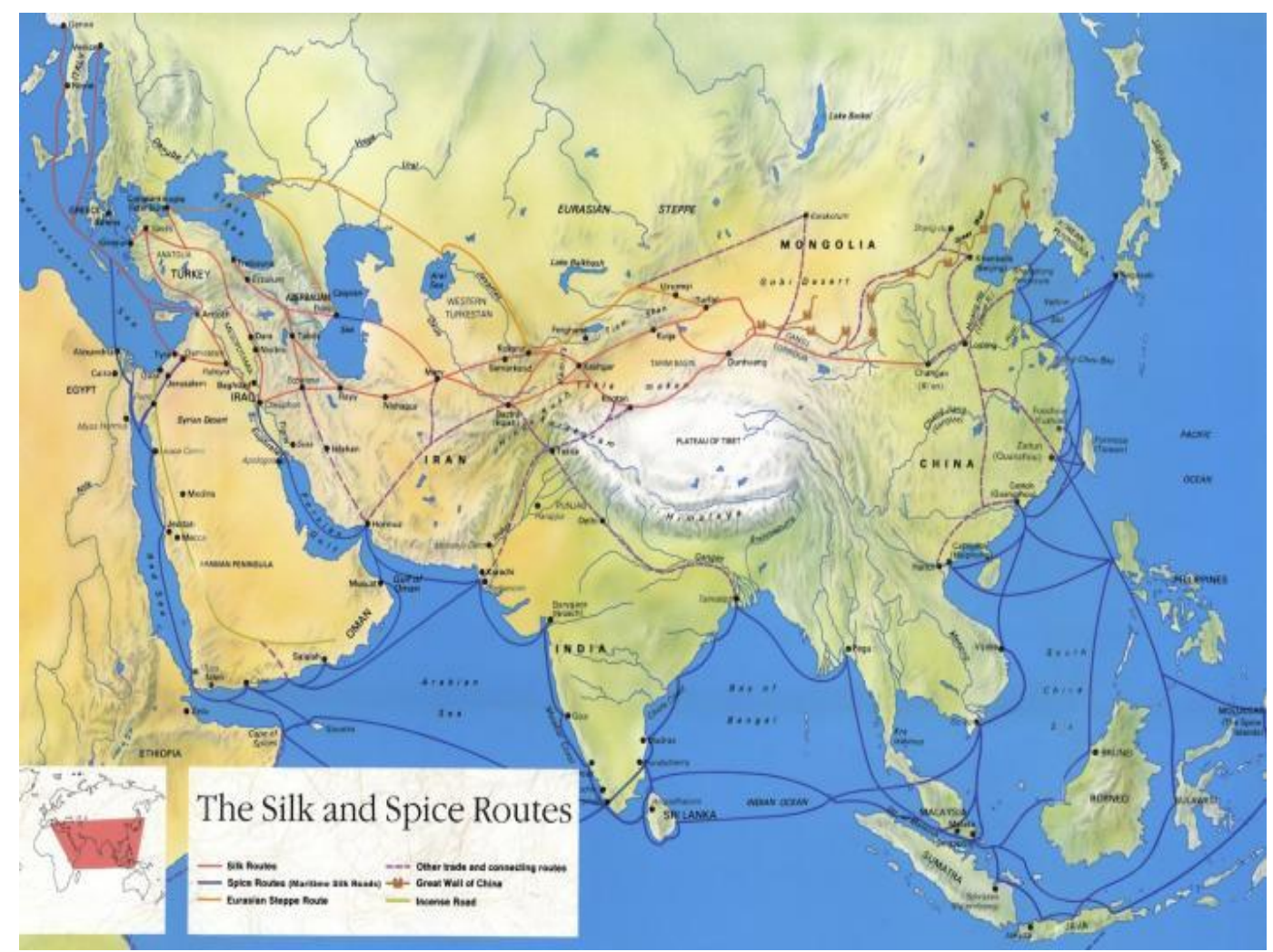

Figure 1: The Silk Road Online Map

The journey and humanity

The journey is an archetypal action of the hero and legend. In epic, the journey has been historicized; in myth, it is universalized. Frederick Turner, in Epic: Form, Content, and History, remarkably connects travel to the humanity:

Travel is not merely something humans do, but something constitutive of humanity....Thus the meaning of the quest, the journey, is not just travel itself. To say that its motto is "the journey not the arrival matters" will not do. The arrival, and the departure-point, matter very much too. It is the meaningful 
relation between the journey and home, home is left or arrived at, begun from or found or returned to, that is the point. Home is defined by our departure from it, our discovery of it, and our return to it. What is constitutive of humanity, to revise our previous aphorism, is the finding or recovery of home, a finding or recovery that is accomplished only through journey. (103)

One's motivation to the journey replicates his or her love for home. A departure from home leads him or her to an unknown zone giving him or her new insight and experience to realize his comfort zone. From a distant, he or she realizes an ever increasing intensity of his comfort zone, which is his or her home. When he looks home from a certain distance, he or she looks home different perspectives. His return journey back home gives him totally meaningful perception of his home he grew up and received sources of energy at the earliest. Turner's perception of departure from home and the journey back home resonates Joseph Campbell's three significant stages of the hero's journey.

In The Hero with a Thousand Faces, Campbell clearly illustrates the hero's journey in relation with a transformation of consciousness. His analogy of the hero's mythological journey with man's universal impulse poses marked relationships between myth and history. Campbell the hero follows traces of the mythological hero in his journey to the unknown world:

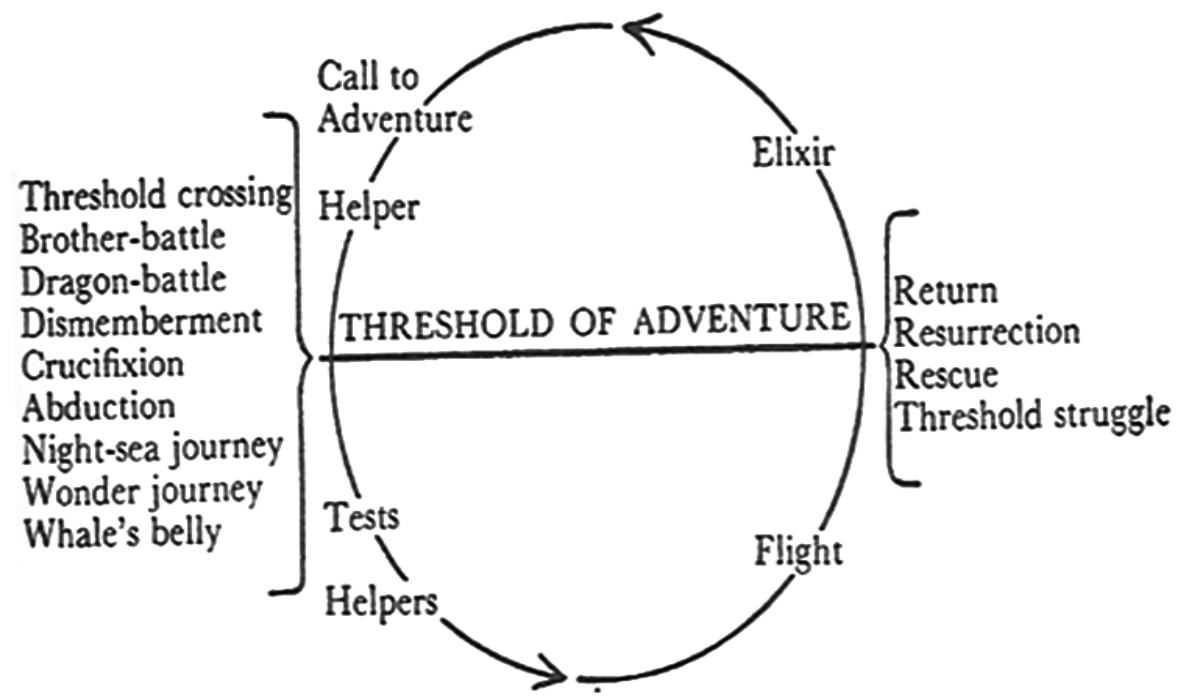

Figure 2: The Hero's Journey

The mythological hero, setting forth from his common day hut or castle, is lured, carried away, or else voluntarily proceeds, to the threshold of adventure. There he encounters a shadow presence that guards the passage. The hero may defeat or conciliate this power and go alive into the kingdom of the dark (brotherbattle, dragon-battle; offering, charm), or be slain by the opponent and descend in death (dismemberment, crucifixion). Beyond the threshold, the, the hero's journeys through a world of unfamiliar yet strangely intimate forces, some of which give magical aid (helpers). When he arrives at the nadir of the mythological round, he undergoes a supreme ordeal and gains his reward. The triumph may be represented as the hero's sexual union with the goddess-mother of the world (sacred marriage), his recognition by the father-creator (fatheratonement), his own divinization (apotheosis), or again - if the powers have 
remained unfriendly to him - his theft of the boon he came to gain (bride-theft, fire-theft); intrisnsically it is an expression of consciousness and herewith of being (illumination, transfiguration, freedom); if not, he flees and is pursued (transformation flight, obstacle flight). At the return threshold the transcendental powers must remain behind; the hero re-emerges from the kingdom of dread (return, resurrection). The boon that he brings restores the world (elixir). (24546)

The geometric circular structure of the journey, an underlying universal pattern of the hero's movement reflects in people's everday life. Some move from villages to cities for job opportunities; others travel to colleges and universities in different parts of the world. Students graduate from their schools, puruse jobs in companies, and farmers plant crops and harvest grains to feed their children. All of them pay price for some returns, sacrifice their selves in the best interest of their families or societies, and ultimately return their home to share boons. Not only the hero's journey but also architectural structure of holy sites replicate circular images,

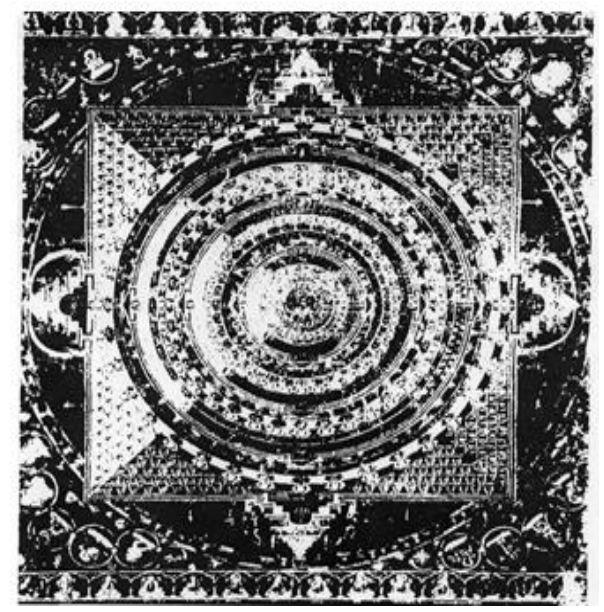

Figure 3: Mandala

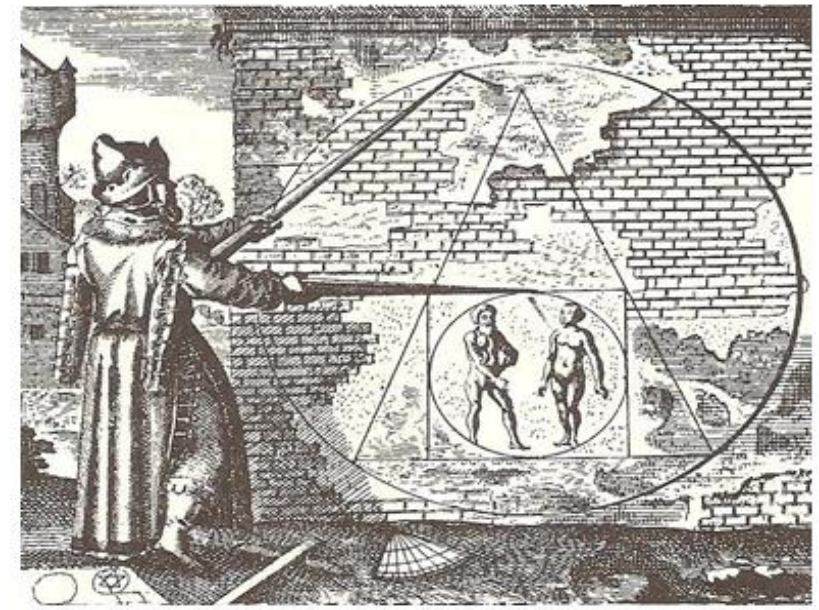

Figure 4: The Geometric Circular Structure

Embodiments of purity, wholeness, and perfection. The geometric circular structure of myth and journey dominate American films as well. Like many of the archetypal heroes, Elliott in Steven Spielberg-directed E.T.: The 
Extraterrestrial faces circular images in flashes of lights and scenic landscapes at night, suggesting the hero's quest myth.

The Chinese businessmen's Silk Road journey to the West reflects power and prosperity. Merchants from China and India used to make their business trips to Europe and America, and their brought with them materials required for household and business purposes. By the second century CE, the Palmyraean merchant caravans carried textiles, including silks, and the Roman market for the goods Palaria obtained from the East were vital to the city's survival (Liu 31). A similar kind of business operates between the East and the West in the making of the world civilizations. Forecasting the Chinese supremacy in the new world order, Former secretary of state of the United States reflects the trade and commerce through the Silk Road: "The two civilizations, Indian and Chinese, exchanged goods and Buddhist influences along the Silk Road but were elsewhere walked off casual contact by the almost impenetrable Himalayas and Tibetan Plateau" (Kissinger 8). Not only did the Silk Road business in the past connect the West and the East but also fostered relationships between the two global spheres. At present, the Chinese Silk Road business has further expanded in South Asia, Europe, America and the Persian Gulf.

Around the fifth and sixth BCE, the Silk business and the Buddhist preaching spread across the Indian Ocean expanding further across the Pacific and the Atlantic. Both the Silk Road business and the Buddhist philosophy complementarily supported to accelerate the economic progress and prosperity, especially that of India and China. The Silk Road merchants and the Buddhist monks became leading representatives for the promotion of international trade and business along with continued dissemination of the Buddhist preaching. The Buddhist sangha turned a cultural center for the spread of the Buddhist dharma across the world, originating from the Asian continent.

During the medieval period, the circular image embodies perfection. In changing paradigms in science and technology, the medieval time could see a union between the sacred and the profane, terrestrial and celestial, and earthly and heavenly. For an example, the circular image of the mandala in the Buddhist monasteries and temples dominates the entire history of Eastern civilization. Beyond the Eastern art and architecture, the mandala structure appears in American popular movies, such as E.T., Close Encounters and 2001: A Space Odyssey. Among them E.T. and 2001 predominately square the mandala imagery.

The word 'mandala,' from the Sanskrit for circle, is also the term used by Indians for the circles drawn in religious contemplations. According to Jung, the most significant mandalas are found in Tibetan Buddhism. For the Tibetan Buddhist the mandala is ritually used as a "yantra," as instrument of contemplation. The goal of such contemplation is for the yogi to "become inwardly aware of the deity. Through contemplation, he recognizes himself as God again, and thus, returns from the illusion of individual existence into the universal totality of the divine state. (Mackey-Kallis 164)

The mandala symbols in these American movies reinforce a strong bond between the two worlds, the East and the West. This circular structure of the mandala symbol becomes an archetype for the Silk Road journey the Chinese 
merchants and the Buddhist monks rework ever since the rise of the Chinese civilization in the East.

The Silk Road journey of the merchant conforms to the Buddhist monk's preaching across the world starting from the Asian continent in the East. In that line, pilgrims supported the business, and the latter made life prosperous. Merchants' donations to monasteries became important source of religious establishment, and their beliefs in spirituality mark remarkable connection between economics and religion, a central guideline in the Silk Road link.

\section{Works Cited}

Barthes, Roland. Mythologies. Trans. Annette Lavers. New York: Hill and Wang, 1972. Print.

Campbell, Joseph. The Hero with a Thousand Faces. New York: Princeton U Press, 1972. Print.

Eagleton, Terry. The Idea of Culture. Oxford, UK: Blackwell, 2000. Print.

Gasset, José Ortega y. The Dehumanization of Art. Princeton, New Jersey: Princeton U P, 1972. Print.

Gay, Paul Du. Doing Cultural Studies: the Story of the Sony Walkman. Princeton, New Jersey: Princeton U P, 1995. Print.

Hall, Stuart, ed. The Representation: Cultural Representations and Signifying Practices. London: Sage Publications, 2003. Print.

Kissinger, Henry. On China. New York: Penguin, 2012. Print.

Liu, Xinru. The Silk Road World History. Oxford: Oxford U Press, 2010. Print.

Mackey-Kallis, Susan. The Hero and the Perennial Journey Home in American Film. Philadelphia: U of Pennsylvania Press, 2001. Print.

Storey, John. Cultural Studies and the Study of Popular Culture. Athens, Georgia: University of Georgia Press, 1996. Print.

Tyson, Lois. A Critical Theory Today. New York: Routledge, 2006.

Williams, Raymond. Keywords: A Vocabulary of Culture and Society. New York: Oxford U Press, 1985. Print. 